\title{
Competitive Ligand Exchange and Dissociation in Ru Indenyl Complex-
} es

\author{
Roman G. Belli*, Yang Wu*, Hyewon Ji, Anuj Joshi, Lars P. Yunker, Lisa Rosenberg*, J. Scott McIn- \\ doe*
}

\$These authors contributed equally.

Department of Chemistry, University of Victoria, P. O. Box 1700, STN CSC, Victoria, British Columbia, Canada V8W 2Y2 Supporting Information Placeholder

\begin{abstract}
Kinetic profiles obtained from monitoring the solution phase substitution chemistry of [Ru( $\eta^{5}$ indenyl $\left.)(\mathrm{NCPh})\left(\mathrm{PPh}_{3}\right)_{2}\right]^{+}(\mathbf{1})$ by both ESI-MS and ${ }^{31} \mathrm{P}\left\{{ }^{1} \mathrm{H}\right\}$ NMR are essentially identical, despite an enormous difference in sample concentrations for these complementary techniques. These studies demonstrate dissociative substitution of the NCPh ligand in $\mathbf{1}$. Competition experiments using different secondary phosphine reagents provide a ranking of phosphine donor abilities at this relatively crowded half-sandwich complex: $\mathrm{PEt}_{2} \mathrm{H}>\mathrm{PPh}_{2} \mathrm{H} \gg \mathrm{PCy}_{2} \mathrm{H}$. The impact of steric congestion at $\mathrm{Ru}$ is evident also in reactions of 1 with tertiary phosphines; initial substitution products $\left[\mathrm{Ru}\left(\eta^{5} \text {-indenyl }\right)\left(\mathrm{PR}_{3}\right)\left(\mathrm{PPh}_{3}\right)_{2}\right]^{+}$rapidly lose $\mathrm{PPh}_{3}$, enabling competitive recoordination of $\mathrm{NCPh}$. Further solution experiments, relevant to the use of $\mathbf{1}$ in catalytic hydrophosphination, show that $\mathrm{PPh}_{2} \mathrm{H}$ out-competes $\mathrm{PPh}_{2} \mathrm{CH}_{2} \mathrm{CH}_{2} \mathrm{CO}_{2} \mathrm{Bu}^{t}$ (the product of hydrophosphination of tert-butyl acrylate by $\mathrm{PPh} / \mathrm{H}$ ) for coordination to $\mathrm{Ru}$, even in the presence of a ten-fold excess of the tertiary phosphine. Additional information on relative phosphine binding strengths was obtained from gas-phase MS/MS experiments, including collision-induced dissociation (CID) experiments on the mixed phosphine complexes $\left[\mathrm{Ru}\left(\eta^{5} \text {-indenyl)PP' } \mathrm{P}^{\prime}\right]^{+}\right.$, which ultimately appear in solution during the secondary phosphine competition experiments. Unexpectedly, unsaturated complexes $\left[\mathrm{Ru}\left(\eta^{5} \text {-indenyl }\right)\left(\mathrm{PR}_{2} \mathrm{H}\right)\left(\mathrm{PPh}_{3}\right)\right]^{+}$, generated in the gas-phase, undergo preferential loss of $\mathrm{PR}_{2} \mathrm{H}$. We propose competing orthometallation of $\mathrm{PPh}_{3}$ is responsible for the surprising stability of the [Ru( $\eta^{5}$ indenyl $\left.)\left(\mathrm{PPh}_{3}\right)\right]^{+}$fragment under these conditions.
\end{abstract}

\section{INTRODUCTION}

We recently reported the activity of a series of $\mathrm{Ru}\left(\eta^{5}-\right.$ indenyl) complexes in the catalytic hydrophosphination of activated alkenes. ${ }^{1}$ Although participation of this halfsandwich species in C-C bond-forming catalysis is wellestablished, ${ }^{2}$ its activity for heteroatom addition chemistry such as hydrophosphination remains relatively underexplored. ${ }^{3}$ Our preliminary investigations of this catalysis show that competing coordination of substrate secondary phosphine $\mathrm{PR}_{2} \mathrm{H}$, ancillary $\mathrm{PPh}_{3}$, and product tertiary phosphine $\mathrm{PR}_{2} \mathrm{R}^{\prime}$ at $\mathrm{Ru}$ in this system plays an important role in the speciation of the catalyst during the reaction. For example, ${ }^{31} \mathrm{P}\left\{{ }^{1} \mathrm{H}\right\}$ NMR spectra of catalytic mixtures from our preliminary studies show signals for multiple Ru-P-containing products, attributable to species containing one, two and three different phosphine ligands. ${ }^{1}$ The possibility of product inhibition is a concern in harnessing such late metal systems in catalytic hydrophosphination, but its importance will be highly susceptible to the complex balance of steric and electronic effects governing reactivity at this relatively crowded $\mathrm{Ru}$ center.

The coordination behaviour of phosphine ligands is welldocumented and even quantified, ${ }^{4}$ but most data concerning their steric and electronic properties has been gathered for tertiary phosphines. It is possible to estimate Tolman cone angles $^{5}$ or other steric parameters ${ }^{6}$ for secondary phosphines, but the impact of the $\mathrm{P}-\mathrm{H}$ bond on overall donor ability is not well established. Thus, the synthesis and reactivity of $\mathrm{Ru}\left(\eta^{5}-\right.$ indenyl) mixed phosphine complexes are important to our ongoing studies and optimization of hydrophosphination catalysis, and we have a particular interest in evaluating the behavior of secondary phosphines within the Ru coordination sphere. $^{7}$

Scheme 1. Activity of cation 1 for hydrophosphination

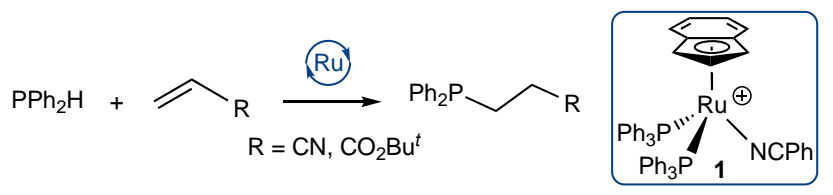

Among catalyst precursors we assessed in the hydrophosphination reactions of diphenylphosphine was $\left[\mathrm{Ru}\left(\eta^{5}-\right.\right.$ indenyl) $\left.(\mathrm{NCPh})\left(\mathrm{PPh}_{3}\right)_{2}\right]^{+}(\mathbf{1}$, Scheme 1). Cations such as $\mathbf{1}$ and its phosphine-substituted derivatives are straightforward to analyze by ESI-MS, ${ }^{8}$ since they are readily transferred from solution phase to gas phase during the electrospray process without any need for adventitious association with some other charged species. ${ }^{9}$ Indeed, we previously exploited the electrospray technique to determine $\mathrm{Ru}-\mathrm{P}$ bond dissociation energies (BDEs) for $\left[\mathrm{Ru}\left(\eta^{5} \text {-indenyl }\right)\left(\mathrm{PPh}_{2} \mathrm{H}\right)_{3}\right]^{+}$using Fourier transform ion cyclotron resonance mass spectrometry (FTICRMS). ${ }^{10}$ Those quantitative studies involved collision-induced dissociation (CID) of mass-selected ions within the FTICR 
cell, and provided a lower limit for the $\mathrm{Ru}-\mathrm{PPh}_{2} \mathrm{H}$ bond dissociation energy (BDE) of $16.6 \mathrm{kcal} / \mathrm{mol}$. We noted the difficulty in comparing this absolute, gas phase value for an $\eta^{5}$ indenyl system with $\mathrm{BDE}$ values for $\mathrm{Ru}-\mathrm{PR}_{3}$ available from solution calorimetry studies of tertiary phosphine substitutions at $\left\{\mathrm{Ru}\left(\eta^{5}-\mathrm{Cp} \mathrm{p}^{*}\right) \mathrm{Cl}\right\}_{4}$, given the dependence of the calorimetryderived values on solvent and temperature, and the observed strong correlation of BDEs for the $\eta^{5}-\mathrm{Cp}^{*}$ system with steric, as opposed to electronic, properties of the tertiary phosphines studied. ${ }^{11}$ Ideally, a clearer picture of the relative binding energies of phosphines could be obtained by performing these painstaking CID studies on a broad range of analogous cationic complexes for a given half-sandwich system.

A simple and useful alternative for ranking the affinity of disparate phosphines at a single, cationic metal fragment is the study of its substitution reactions in real time using the "pressurized sample infusion mass spectrometry" (PSI-ESI-MS) technique. ${ }^{12}$ In these experiments a continuous flow of the stirred reaction mixture in solution is transferred directly into the spectrometer under a pressure of $\leq 5$ psi of inert gas. Provided the incoming and outgoing ligands differ in mass (e.g. a competition experiment between $\mathrm{P}^{t} \mathrm{Bu}_{3}$ and $\mathrm{P}^{n} \mathrm{Bu}_{3}$ would be uninformative), time-resolved speciation of all cationic complexes in the mixture will result. Here we report the use of PSI-ESI-MS to measure the relative kinetics of competitive phosphine substitution reactions at complex $\mathbf{1}$, and we confirm the results using ${ }^{31} \mathrm{P}\left\{{ }^{1} \mathrm{H}\right\}$ NMR analysis. These experiments, complemented by further assessment in the gas phase of the relative binding strengths of different phosphines in the mixed phosphine substitution products $\left[\mathrm{Ru}\left(\eta^{5}\right.\right.$-indenyl)PP'P'] + , have allowed us to rank a group of secondary and tertiary phosphines in terms of their affinities for the cationic ruthenium center in this half-sandwich system.

\section{RESULTS AND DISCUSSION}

\section{Substitution kinetics from PSI-ESI-MS and ${ }^{31} P\left\{{ }^{1} H\right\} N M R$}

The benzonitrile (NCPh) ligand in cation $\mathbf{1}$ is easily displaced by a variety of phosphines. Indeed, the lability of NCPh in this complex is such that unless very gentle ionization conditions are used in the ESI-MS experiment (cone voltage 10 $\mathrm{V}),{ }^{13}$ a significant proportion of the observed ion intensity involves the coordinatively unsaturated $\left[\mathrm{Ru}\left(\eta^{5}\right.\right.$ indenyl $\left.\left(\mathrm{PPh}_{3}\right)_{2}\right]^{+}$, from which the $\mathrm{NCPh}$ has been lost in the desolvation process. Examination by PSI-ESI-MS of the reactivity of 1 toward a series of phosphines $\left(\mathrm{PPh}_{2} \mathrm{H}, \mathrm{PEt}_{2} \mathrm{H}\right.$, $\mathrm{PCy}_{2} \mathrm{H}, \mathrm{PBu}_{3}{ }_{3}$ ) shows that the rate of substitution is insensitive to the identity and concentration of the incoming ligand (vide infra), consistent with a dissociative substitution mechanism (Scheme 2). This result might seem surprising in the context of the "indenyl effect", an observation that indenyl complexes tend to have accelerated substitution reactions relative to their $\mathrm{Cp}$ analogues. The rate enhancement is commonly attributed to the coordinative flexibility of the indenyl ligand in swapping between $\eta^{5}$ - and $\eta^{3}$-modes, which can facilitate an associative substitution mechanism. ${ }^{14}$ However, explicit examples of such variable indenyl ligand hapticity do not include ruthenium complexes. ${ }^{15}$ A study on the insertion of alkynes into the $\mathrm{Ru}-\mathrm{H}$ bond of $\mathrm{RuH}\left(\eta^{5}\right.$-indenyl)(dppm) found evidence for an associative mechanism, but the authors acknowledge that either hapticity change of the indenyl ligand or ring-opening of the strained bis(diphenylphosphino)methane ligand could allow binding of the alkyne substrate. ${ }^{16 a}$ Moreover, a kinetic analysis of the accelerated rate of phosphine substitution at $\mathrm{RuCl}\left(\eta^{5}\right.$-indenyl) $\left(\mathrm{PPh}_{3}\right)_{2}$ (the neutral precursor to complex 1) relative to its $\eta^{5}-\mathrm{Cp}$ analogue found clear evidence for a dissociative mechanism in both cases. ${ }^{16 \mathrm{~b}}$ In that report, the enhanced rate of substitution at the $\eta^{5}$-indenyl complex (i.e. the indenyl effect) was attributed to the ability of the electron-rich indenyl ligand to stabilize the 16-electron intermediate formed via a dissociative substitution pathway. ${ }^{17}$

Despite the dissociative nature of these NCPh substitution reactions, when we monitor by PSI-ESI-MS the addition of a 1:1 mixture of $\mathrm{PEt}_{2} \mathrm{H}$ and $\mathrm{PPh}_{2} \mathrm{H}$ (10 equivalents each) to $\mathbf{1}$, the time-dependent distribution of cationic species reveals a dependence of the product ratio on the nature of the incoming ligand (Figure 1a). The relative amounts of the two products formed, $\quad\left[\mathrm{Ru}\left(\eta^{5} \text {-indenyl }\right)\left(\mathrm{PPh}_{3}\right)_{2}\left(\mathrm{PPh}_{2} \mathrm{H}\right)\right]^{+}(\mathbf{2 a})$ and $\left[\mathrm{Ru}\left(\eta^{5}-\right.\right.$ indenyl $\left.)\left(\mathrm{PPh}_{3}\right)_{2}\left(\mathrm{PEt}_{2} \mathrm{H}\right)\right]^{+}(\mathbf{2 b})$ tell us about the relative rates of the rapid second step in the dissociative substitution (Scheme 2): $\mathrm{PEt}_{2} \mathrm{H}$ reacts slightly faster than $\mathrm{PPh}_{2} \mathrm{H}$ with the unsaturated, $16 \mathrm{e}^{-}$intermediate $\left[\mathrm{Ru}\left(\eta^{5} \text {-indenyl }\right)\left(\mathrm{PPh}_{3}\right)_{2}\right]^{+}$, giving a higher proportion of product $\mathbf{2 b}$ (Scheme 2). This is consistent with the fact that $\mathrm{PEt}_{2} \mathrm{H}$ is smaller and more electron-rich than $\mathrm{PPh}_{2} \mathrm{H}$; it is a stronger donor ligand.

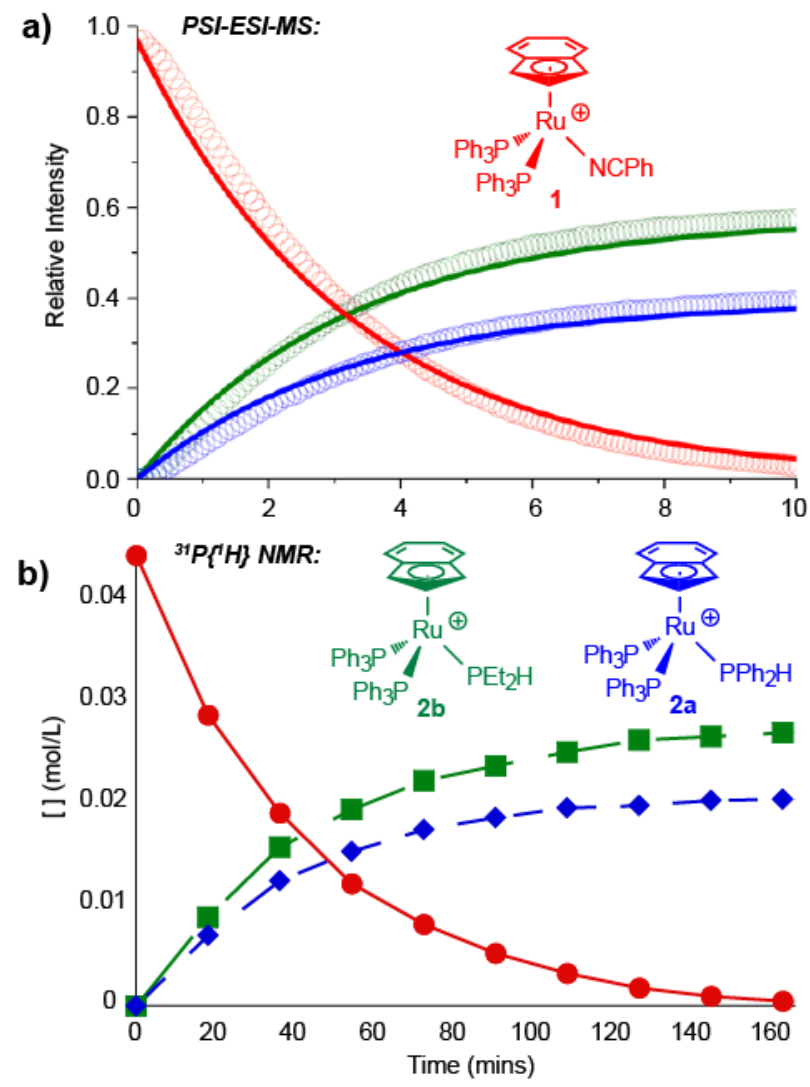

Figure 1. (a) Competitive reactions of 1 with a 10:10 mixture of $\mathrm{PPh}_{2} \mathrm{H}: \mathrm{PEt}_{2} \mathrm{H}$ at $45^{\circ} \mathrm{C}$ in $\mathrm{PhF}$, as monitored by PSI-ESI-MS. Circles are normalized experimental data; lines are simulated using parameter estimation with COPASI. (b) $145.85 \mathrm{MHz}{ }^{31} \mathrm{P}\left\{{ }^{1} \mathrm{H}\right\}$ NMR data for the same experiment in $2: 1 \mathrm{CH}_{2} \mathrm{Cl}_{2} / \mathrm{C}_{6} \mathrm{D}_{6}$ at $\mathrm{RT}$. 
Scheme 2. Competitive substitution of the nitrile ligand in 1 with a mixture of $\mathrm{PPh}_{2} \mathrm{H}$ and $\mathrm{PEt}_{2} \mathrm{H}$
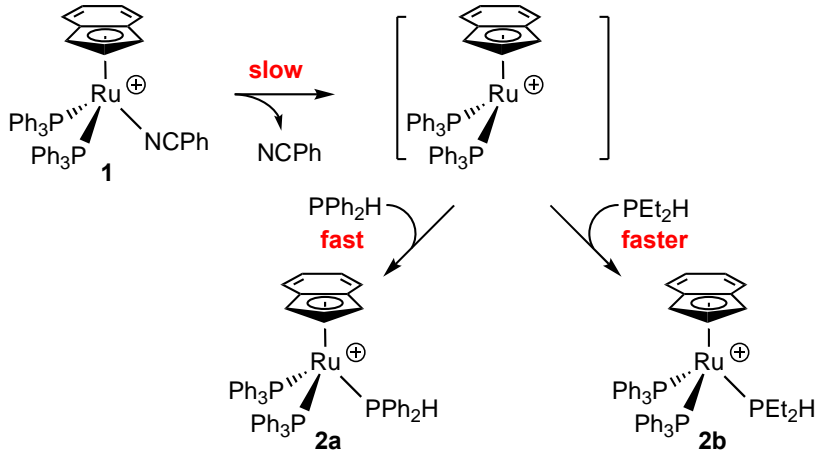

The kinetic profile we observe for this competition experiment by ESI-PSI-MS was confirmed by an analogous experiment monitored by ${ }^{31} \mathrm{P}\left\{{ }^{1} \mathrm{H}\right\}$ NMR (Figure 1b). These two experiments were carried out under strikingly different conditions. Most obvious is the much higher sample concentration required for NMR, relative to MS. However, the effective sampling frequency also differs for the two techniques; the ESI-MS experiment produces one spectrum per second, while the relatively long delays used to render the ${ }^{31} \mathrm{P}\left\{{ }^{1} \mathrm{H}\right\}$ NMR experiment approximately quantitative gave us one spectrum (128 scans) per 20 minutes. To address this difference, we conducted the NMR experiment at room temperature instead of $45^{\circ} \mathrm{C}$, to slow it down. Based on the rule of thumb that reaction rates double with each increase in temperature of $10^{\circ} \mathrm{C},{ }^{18}$ the NMR experiment should take about $5 \times$ as long as the PSIMS experiment, for this $24^{\circ} \mathrm{C}$ difference. The consumption of $\mathbf{1}$ to give $\mathbf{2 a}$ and $\mathbf{2 b}$ as monitored by NMR actually took about $18 \times$ as long (180 $\mathrm{min}$ as opposed to $10 \mathrm{~min}$ at $45^{\circ} \mathrm{C}$ when monitored by ESI-MS); however further slowing of NMR tube reactions can occur due to poor mixing. ${ }^{19}$ Nevertheless, the two kinetic profiles shown in Figure 1 are essentially identical. Given the factor of three million between concentrations used for the MS and NMR experiments, this is compelling evidence for the cleanly dissociative nature of the substitution reaction and for the coordination behaviors of these two secondary phosphines.

To tease out electronic vs. steric effects we also compared the reactions of $\mathrm{PPh}_{2} \mathrm{H}$ and $\mathrm{PCy}_{2} \mathrm{H}$ with complex 1, since $\mathrm{PCy}_{2} \mathrm{H}$ has similar electronic properties to $\mathrm{PEt}_{2} \mathrm{H}$ but is significantly bulkier (its cone angle of $148^{\circ}$ is actually slightly larger than that of $\left.\mathrm{PPh}_{3}=145^{\circ}\right){ }^{4 \mathrm{~d}}$ The MS and NMR results in Figure 2 show clearly the importance of steric hindrance of the incoming phosphine; $\left[\mathrm{Ru}\left(\eta^{5} \text {-indenyl }\right)\left(\mathrm{PPh}_{3}\right)_{2}\left(\mathrm{PCy}_{2} \mathrm{H}\right)\right]^{+}(\mathbf{2 c})$ forms much more slowly than the $\mathrm{PPh}_{2} \mathrm{H}$ complex $\mathbf{2 a}$.

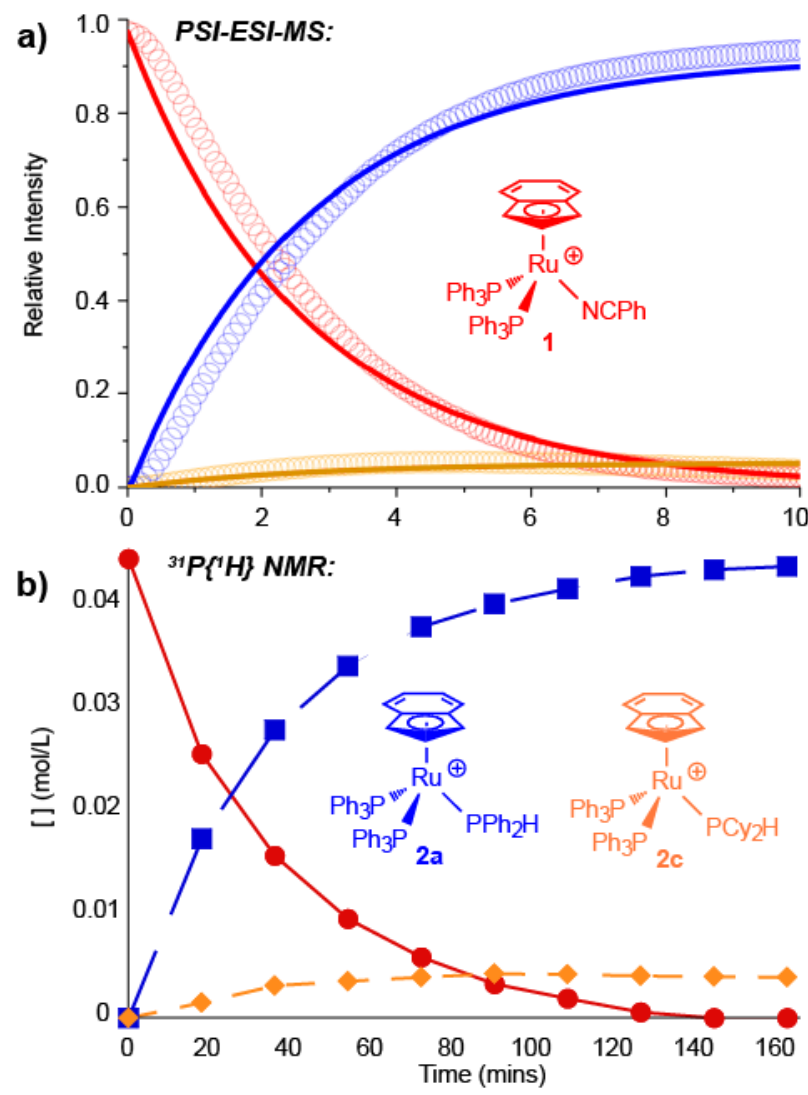

Figure 2. (a) Competitive reactions of 1 with a 10:10 mixture of $\mathrm{PPh}_{2} \mathrm{H}$ and $\mathrm{PCy}_{2} \mathrm{H}$ at $45^{\circ} \mathrm{C}$ in $\mathrm{PhF}$, as monitored by PSI-ESI-MS. Circles are normalized experimental data; the lines were simulated using parameter estimation in COPASI. (b) $145.85 \mathrm{MHz}$ ${ }^{31} \mathrm{P}\left\{{ }^{1} \mathrm{H}\right\} \mathrm{NMR}$ data for the same experiment in $2: 1 \mathrm{CH}_{2} \mathrm{Cl}_{2} / \mathrm{C}_{6} \mathrm{D}_{6}$ at RT.

Based on the results shown in Figures 1 and 2, the relative reactivity of these three secondary phosphines in the substitution of $\mathrm{NCPh}$ in 1 is $\mathrm{PEt}_{2} \mathrm{H}>\mathrm{PPh}_{2} \mathrm{H} \gg \mathrm{PCy}_{2} \mathrm{H}$. We used $\mathrm{COPASI}^{20}$ to model the traces provided by ESI-MS, to extract kinetic parameters for the competitive substitution reactions (solid lines in Figures $1 \mathrm{a}$ and $2 \mathrm{a}$ ). ${ }^{21}$ Along with the timedependent speciation data, COPASI is given the starting concentrations and the predicted sequence of elementary steps (e.g. Scheme 2). COPASI then fits the data and provides $k_{1}$ (rate constant for the nitrile dissociation, and for the overall reaction); it also simulates accurately the ratios of the two $k_{2}$ values, i.e. how much faster one of these fast, subsequent phosphine association steps is than the other. The modeling is consistent with rates for these association reactions that are very fast regardless of the incoming phosphine. Since the simulation involved a relatively large number of independent parameters, we tested the rate constants resulting from one set of initial concentrations (e.g. 10 equivalents of the 1:1 phosphine mixture, Figures 1 and 2) against a different set of initial concentrations (e.g. 100 equivalents of the phosphines, Figures S3, S5). Under these conditions, the simulation changed in the same way as the experimental data. These results not only validate the modeling but also provide further support for the dissociative nature of the reaction, since the overall rate of reaction remains the same with the concentration change (falling in the range $k_{1}=0.006 \pm 0.001$ for all experiments). 
The trialkylphosphine $\mathrm{PBu}_{3}{ }_{3}$ showed more complex reactivity with cation $\mathbf{1}$ than did the secondary phosphines (Figure 3). Since there were multiple products, we did not pursue competition experiments and instead examined just the simple substitution of $\mathrm{NCPh}$ in 1 with $\mathrm{PBu}_{3}{ }_{3}$. The rate of disappearance of $\mathbf{1}$ is the same as in all previous experiments, but the subsequent reactivity is more complex. As shown in Scheme 3 , the first species to occupy the vacant coordination site in the unsaturated intermediate $\left[\mathrm{Ru}\left(\eta^{5} \text {-indenyl }\right)\left(\mathrm{PPh}_{3}\right)_{2}\right]^{+}$is $\mathrm{PBu}_{3}{ }_{3}$, which is present in large excess. However, the resulting complex $\left[\mathrm{Ru}\left(\eta^{5} \text {-indenyl }\right)\left(\mathrm{PPh}_{3}\right)_{2}\left(\mathrm{PBu}_{3}{ }_{3}\right)\right]^{+}(\mathbf{2 d})$ forms only transiently (Figure $3 b$ ); it never reaches more than $10 \%$ of the initial abundance of $\mathbf{1}$. Complex $\mathbf{2 d}$ decomposes to two new complexes, $\quad\left[\mathrm{Ru}\left(\eta^{5} \text {-indenyl }\right)\left(\mathrm{PPh}_{3}\right)\left(\mathrm{PBu}_{3}\right)_{2}\right]^{+} \quad$ (3d) and $\left[\mathrm{Ru}\left(\eta^{5} \text {-indenyl }\right)\left(\mathrm{PPh}_{3}\right)\left(\mathrm{PBu}_{3}{ }_{3}\right)(\mathrm{NCPh})\right]^{+}(\mathbf{4 d})$, which correspond to the substitution of one $\mathrm{PPh}_{3}$ ligand in $\mathbf{2 d}$ by $\mathrm{PBu}_{3}$ and $\mathrm{NCPh}$, respectively (Scheme 3). The ratio of $\mathbf{3 d}$ and $\mathbf{4 d}$ formed depends on the amount of $\mathrm{PBu}_{3}$ added: smaller excesses of $\mathrm{PBu}_{3}^{n}$ produce less of the former (Figures S8, S9).
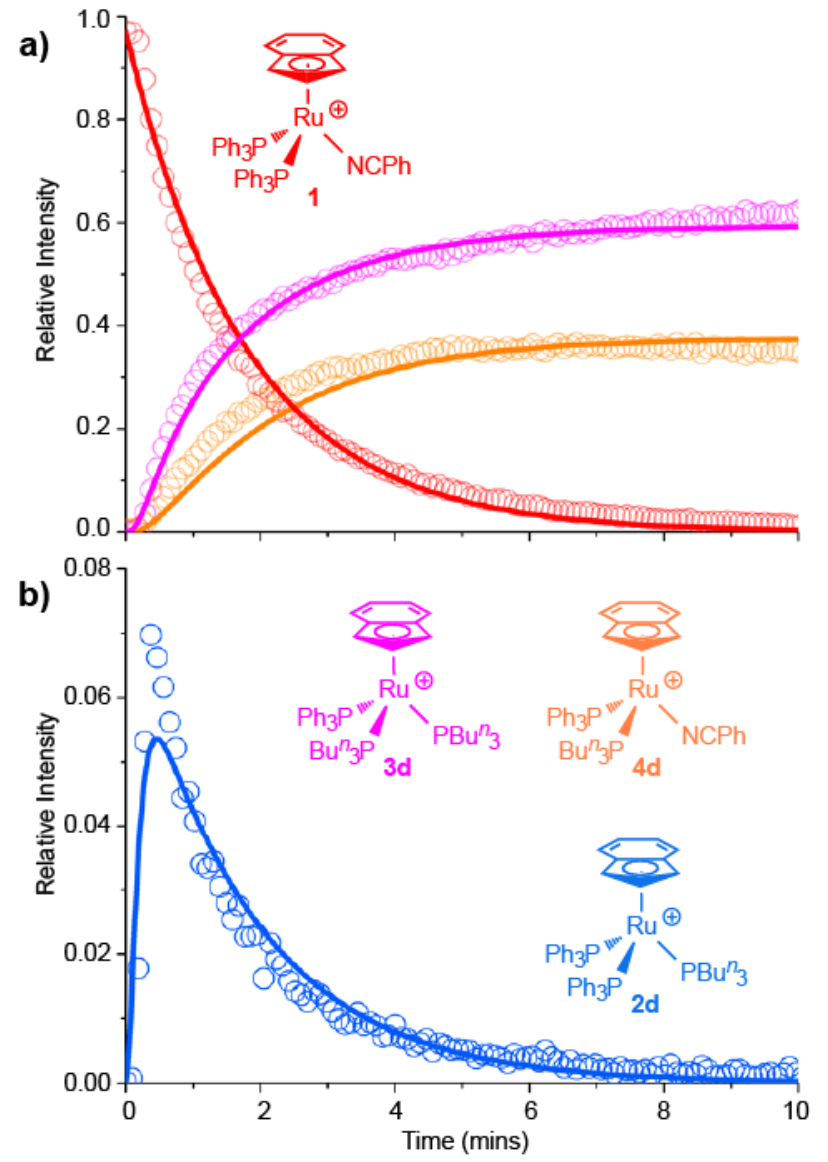

Figure 3. (a) Reaction of 1 with 100 equivalents of $\mathrm{PBu}^{n}{ }_{3}$ at $45^{\circ} \mathrm{C}$ in $\mathrm{PhF}$, as monitored by PSI-ESI-MS. Circles are normalized experimental data and solid lines were simulated using COPASI. The different intensity scale in (b) highlights the low concentrations of transiently formed $\mathbf{2 d}$. In MS experiments using 50 and 10 equivalents $\mathrm{PBu}_{3}{ }_{3}$, signal due to this complex falls much lower in the baseline, and $\mathbf{2 d}$ was not detected in the corresponding ${ }^{31} \mathrm{P}\left\{{ }^{1} \mathrm{H}\right\} \mathrm{NMR}$ experiment (10 equivalents $\mathrm{PBu}^{n}{ }_{3}$, Figures S6, S7).
Scheme 3. Reaction sequence used to model MS data for addition of excess $\mathrm{PBu}^{n}{ }_{3}$ to 1 from Figure 3
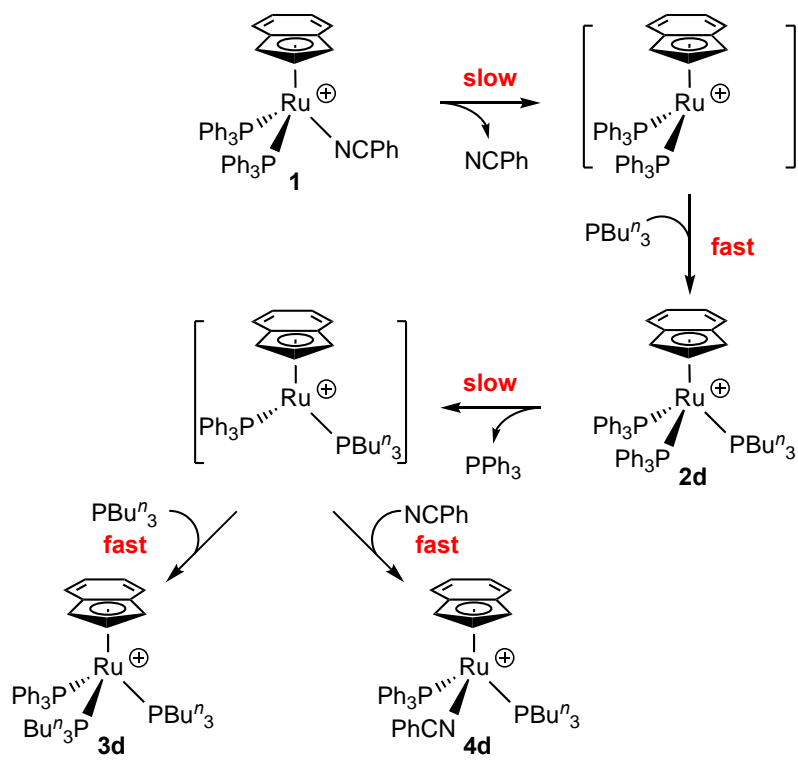

The results shown in Figure 3 indicate that the $\mathrm{PPh}_{3}$ ligands in $\mathbf{2 d}$ are labilized by the initial replacement of NCPh in $\mathbf{1}$ by $\mathrm{PBu}_{3}{ }_{3}$, presumably through steric crowding; one $\mathrm{PPh}_{3}$ is then lost quickly (relative to the initial loss of $\mathrm{NCPh}$ ) to form the unsaturated complex $\left[\mathrm{Ru}\left(\eta^{5} \text {-indenyl }\right)\left(\mathrm{PPh}_{3}\right)\left(\mathrm{PBu}_{3}{ }_{3}\right)\right]^{+}$. The solution now contains three possible candidates to occupy that vacant coordination site: one equivalent of $\mathrm{PPh}_{3}$, a large excess of $\mathrm{PBu}_{3}{ }_{3}$, and one equivalent of $\mathrm{NCPh}$. While the $\mathrm{PPh}_{3}$ is clearly uncompetitive (low relative concentration, cone angle $145^{\circ}$ ), a high relative concentration of the somewhat less bulky $\mathrm{PBu}_{3}{ }_{3}\left(\right.$ cone angle $132^{\circ}$ ) allows the formation of $\mathbf{3 d}$. The apparent non-innocence of the nitrile ligand under these conditions is somewhat surprising; despite its much lower relative concentration ( $\mathrm{NCPh}: \mathrm{PBu}^{n}{ }_{3}$ is 1:10, 1:50, or 1:100, vide infra) and its facile loss from $\mathbf{1}$, the much smaller NCPh can reoccupy the vacant site to give $\mathbf{4 d}$, at a rate that is comparable to that for the formation of $\mathbf{3 d}$. The numerical modelling agrees with this sequence of events. Not only did the parameter estimation provide reasonable matches for the experimental data obtained using 100 equivalents of $\mathrm{PBu}_{3}$ (solid lines in Figure 3 ), but also the model responded in the same way as the experiment when the number of equivalents was dropped to 50 and then 10 (Figures S8, S9).

As described in the introduction, these studies of secondary and tertiary phosphine substitution chemistry are relevant to the potential activity of this half sandwich system in the catalytic hydrophosphination of alkenes. ${ }^{1}$ The ability of secondary phosphines to compete effectively with the product tertiary phosphine for binding at Ru will be critical to this activity, and the above results suggest that this should not be a problem, based primarily on steric arguments. Further support for this premise comes from additional experiments examining the reactions of 1 with $\mathrm{PPh}_{2} \mathrm{H}$ and the product of hydrophosphination of tert-butyl acrylate by this secondary phosphine: $\mathrm{PPh}_{2}\left(\mathrm{CH}_{2} \mathrm{CH}_{2} \mathrm{CO}_{2} \mathrm{Bu}^{t}\right)$. The reaction of 1 with just product phosphine gives a relatively similar product distribution to that observed for $\mathrm{PBu}_{3}{ }_{3}$ (vide supra, Figures S10, S11); monitoring by ${ }^{31} \mathrm{P}\left\{{ }^{1} \mathrm{H}\right\}$ shows the nitrile substitution product $2 \mathbf{e}$ forms transiently but the mixed phosphine nitrile complex 
$\left[\mathrm{Ru}\left(\eta^{5} \text {-indenyl }\right)\left(\mathrm{PPh}_{3}\right)\left(\mathrm{PPh}_{2} \mathrm{CH}_{2} \mathrm{CH}_{2} \mathrm{CO}_{2} \mathrm{Bu}^{t}\right)(\mathrm{NCPh})\right]^{+}, \quad \mathbf{4 e}$, ultimately dominates the product mixture. Monitoring this reaction by PSI-ESI-MS shows the same final product distribution, but instead of complex $2 \mathbf{e}$, the apparently unsaturated complex $\quad\left[\mathrm{Ru}\left(\eta^{5} \text {-indenyl }\right)\left(\mathrm{PPh}_{3}\right)\left(\mathrm{PPh}_{2} \mathrm{CH}_{2} \mathrm{CH}_{2} \mathrm{CO}_{2} \mathrm{Bu}^{t}\right)\right]^{+}$is observed transiently. (We attribute formation of this species to facile dissociation of $\mathrm{PPh}_{3}$ from sterically congested 2e during the electrospray process; it may be stabilized in the gas-phase by chelation through the pendant ester group in the tertiary phosphine.) This substitution chemistry may become important towards the end of catalysis when the ratio of product phosphine to substrate $\mathrm{PPh}_{2} \mathrm{H}$ is very high, but in the presence of a 10:10 mixture of $\mathrm{PPh}_{2} \mathrm{H}$ and $\mathrm{PPh}_{2} \mathrm{CH}_{2} \mathrm{CH}_{2} \mathrm{CO}_{2} \mathrm{Bu}^{t}$ only the $\mathrm{PPh}_{2} \mathrm{H}$ complex 2a is observed (Figures S13, S14). Even in a reaction of 1 with a 1:10 mixture of $\mathrm{PPh}_{2} \mathrm{H}$ and $\mathrm{PPh}_{2} \mathrm{CH}_{2} \mathrm{CH}_{2} \mathrm{CO}_{2} \mathrm{Bu}^{t}$, complex 2a dominates and only trace amounts of $\mathrm{PPh}_{2} \mathrm{CH}_{2} \mathrm{CH}_{2} \mathrm{CO}_{2} \mathrm{Bu}^{t}$-containing products are observed, by ESI-MS (e.g. $4 \mathbf{e}$ and $\left[\mathrm{Ru}\left(\eta^{5} \text {-indenyl }\right)\left(\mathrm{PPh}_{3}\right)\left(\mathrm{PPh}_{2} \mathrm{H}\right)\left(\mathrm{PPh}_{2} \mathrm{CH}_{2} \mathrm{CH}_{2} \mathrm{CO}_{2} \mathrm{Bu}^{t}\right)\right]^{+}, \quad$ 6) (Scheme 4, Figure S15). These results indicate that the tertiary product phosphine does not effectively compete with $\mathrm{PPh}_{2} \mathrm{H}$ for coordination at this cationic Ru center.

Scheme 4. Competitive substitution of the nitrile ligand in 1 with a 1:10 mixture of $\mathrm{PPh}_{2} \mathrm{H}$ and $\mathrm{PPh}_{2} \mathrm{CH}_{2} \mathrm{CH}_{2} \mathrm{CO}_{2} \mathrm{Bu}^{t}$; only 2a was observed by NMR; $2 \mathrm{a}, 4 \mathrm{e}$ and 6 were observed by MS.

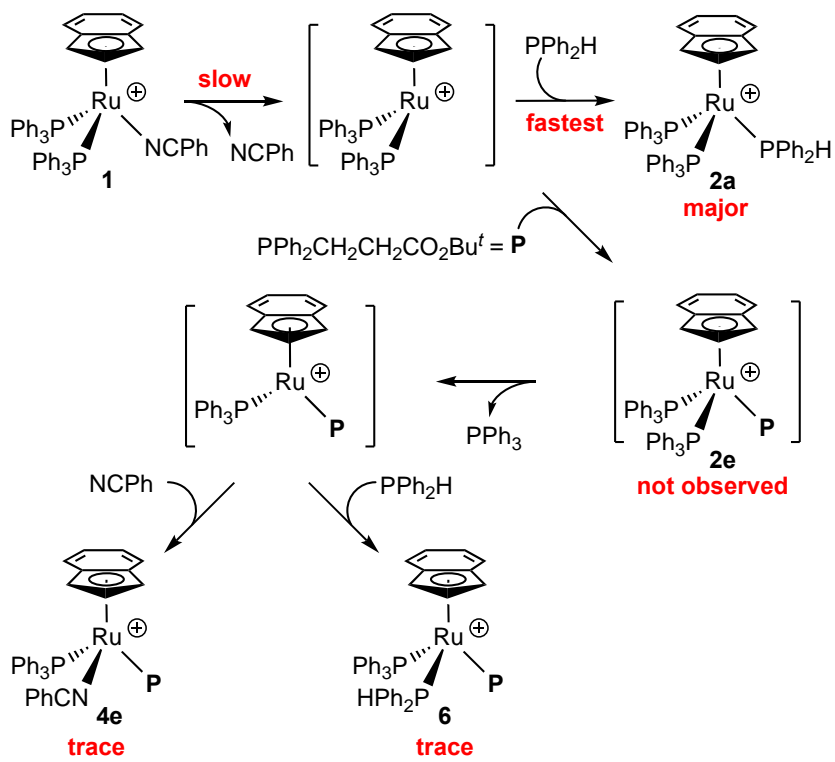

2. MS/MS experiments: an alternative gauge of relative phosphine binding affinities

When the competitive substitution reactions involving addition of two secondary phosphines to complex $\mathbf{1}$ are allowed to reach equilibrium (e.g. $\mathrm{t}>10 \mathrm{~min}$ for the PSI-ESI-MS experiments, after complex 1 has been completely consumed in the initial substitution reactions), the product mixtures include complexes that result from further substitution of the $\mathrm{PPh}_{3}$ ligands in the mixed phosphine complexes 2a-c (e.g. Figures S2, S4). This is a straightforward way to generate complexes of the type $\left[R u\left(\eta^{5} \text {-indenyl)(PP'P") }\right]^{+}\right.$, which provides an opportunity to directly compare the relative binding strength of the phosphine ligands through MS/MS experiments. We can isolate in the gas phase a single $\left[\mathrm{Ru}\left(\eta^{5} \text {-indenyl)(PP'P") }\right]^{+}\right.$ complex from a complicated mixture of other complexes of this type (e.g. $\left[\mathrm{Ru}\left(\eta^{5} \text {-indenyl) } \mathrm{P}_{\mathrm{x}} \mathrm{P}_{\mathrm{y}} \mathrm{P}{ }^{\prime}\right]^{+}{ }^{+}\right.$where $\mathrm{x}, \mathrm{y}, \mathrm{z}=0-3$ and $\mathrm{x}+\mathrm{y}+\mathrm{z}=3)$, and accelerate it through an argon-filled collision cell to initiate energetic collisions and raise the internal energy of the ion to the point that unimolecular decomposition reactions occur, eliminating neutral molecules (most often intact L-type ligands in the first instance) and new product ions. The relative propensity of the complex to lose one or another ligand during this collision-induced dissociation (CID) is gauged by the lowest collision voltage at which the cationic dissociation product is detected and by the relative amount of dissociation product detected as the collision voltage is increased (collectively referred to below as a "track"). Dissociation product tracks tell us about the relative binding strength of the ligands in the complex of interest. ${ }^{22}$ This presents a convenient alternative to actually quantifying ligand binding strength (as described in the introduction), which requires energy-resolved threshold CID techniques that often necessitate instrumentation that is not commercially available, ${ }^{23}$ and relies on clean fragmentation to a single product. ${ }^{24}$

We selected the ion $\left[\mathrm{Ru}\left(\eta^{5}-\right.\right.$ indenyl) $\left.\left(\mathrm{PPh}_{3}\right)\left(\mathrm{PEt}_{2} \mathrm{H}\right)\left(\mathrm{PPh}_{2} \mathrm{H}\right)\right]^{+}$, 7, from the competitive ligand substitution mixture that initially produced complexes $\mathbf{2 a -}$ b (vide supra), and carried out CID over a range of collision voltages. Figure 4 shows the relative intensities (abundances) of 7 and the resulting product ions as a function of collision voltage; these are referred to as "breakdown curves". ${ }^{25}$

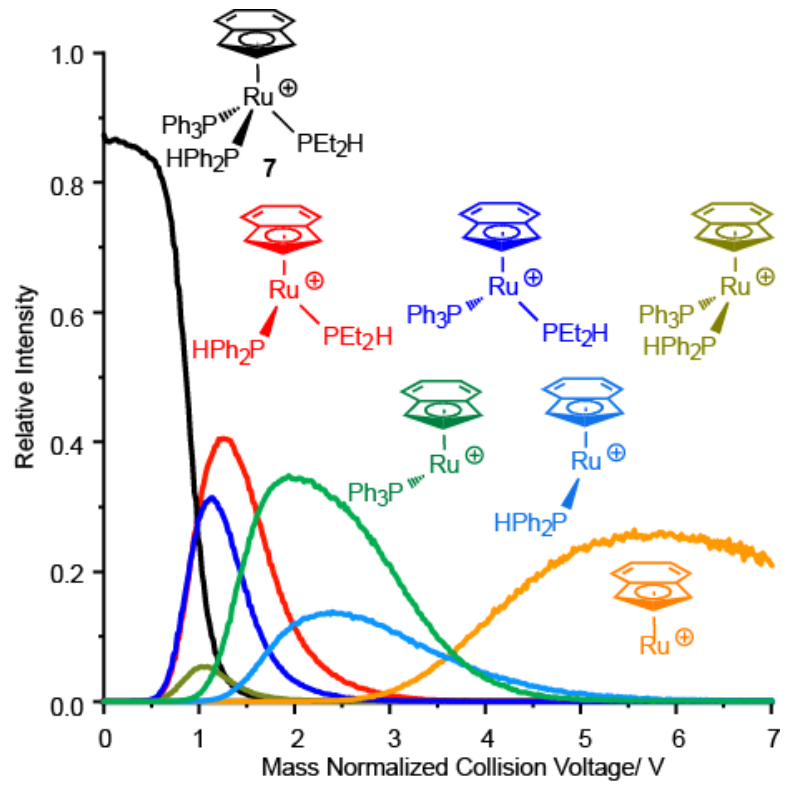

Figure 4. Breakdown curves for the precursor ion $\left[\mathrm{Ru}\left(\eta^{5}-\right.\right.$ indenyl $\left.)\left(\mathrm{PPh}_{3}\right)\left(\mathrm{PEt}_{2} \mathrm{H}\right)\left(\mathrm{PPh}_{2} \mathrm{H}\right)\right]^{+}(7)$.

There are three possible simple ligand dissociations that can occur for complex 7, and we observe all three to varying degrees starting at the minimum voltage of $\sim 0.6 \mathrm{~V}$. The least abundant is the ion generated via loss of $\mathrm{PEt}_{2} \mathrm{H}$, suggesting this ligand is the most tenaciously bound. Ions resulting from loss of $\mathrm{PPh}_{2} \mathrm{H}$ and $\mathrm{PPh}_{3}$ appear with almost identical tracks; overall the three tracks suggest an order of binding strength $\mathrm{PEt}_{2} \mathrm{H}>\mathrm{PPh}_{2} \mathrm{H} \sim \mathrm{PPh}_{3}$. As discussed further below, these product ions themselves are susceptible to further fragmentation via loss of a second phosphine ligand, which is why their relative intensities drop to zero at collision voltages higher than $2 \mathrm{~V}$. Finally, at the highest collision voltages, loss of the 
final phosphine from all three monophosphine species occurs, giving the common, highly unsaturated product $\left[\mathrm{Ru}\left(\eta^{5}-\right.\right.$ indenyl) $]^{+}$.

When the analogous CID experiment was conducted with the ion $\left[\mathrm{Ru}\left(\eta^{5} \text {-indenyl }\right)\left(\mathrm{PPh}_{3}\right)\left(\mathrm{PCy}_{2} \mathrm{H}\right)\left(\mathrm{PPh}_{2} \mathrm{H}\right)\right]^{+}$(8) (Figure $\mathrm{S} 16), \mathrm{PPh}_{3}$ was the ligand most easily lost, with slightly lower and almost identical tracks for loss of $\mathrm{PCy}_{2} \mathrm{H}$ and $\mathrm{PPh}_{2} \mathrm{H}$. This experiment highlights the relative importance of the steric and electronic characters of the phosphines in this half-sandwich system; $\mathrm{PPh}_{3}$ and $\mathrm{PCy}_{2} \mathrm{H}$ have almost identical cone angles, but $\mathrm{PCy}_{2} \mathrm{H}$ should be more Lewis basic, so in this very steri- cally crowded complex $\mathrm{PPh}_{3}$ is the most weakly bound. Collectively, the CID experiments for $\mathbf{7}$ and $\mathbf{8}$ show that the greater steric pressure exerted by $\mathrm{PCy}_{2} \mathrm{H}$ relative to $\mathrm{PEt}_{2} \mathrm{H}$ has the effect of discriminating between $\mathrm{PPh}_{3}$ and $\mathrm{PPh}_{2} \mathrm{H}$, as well as making $\mathrm{PCy}_{2} \mathrm{H}$ significantly easier to dissociate than $\mathrm{PEt}_{2} \mathrm{H}$ in a comparable coordination environment. Overall, a binding strength order between these four ligands emerges as $\mathrm{PEt}_{2} \mathrm{H}>$ $\mathrm{PPh}_{2} \mathrm{H} \sim \mathrm{PCy}_{2} \mathrm{H} \sim \mathrm{PPh}_{3}$, where the order between the last three ligands depends on the steric environment at the metal complex. 

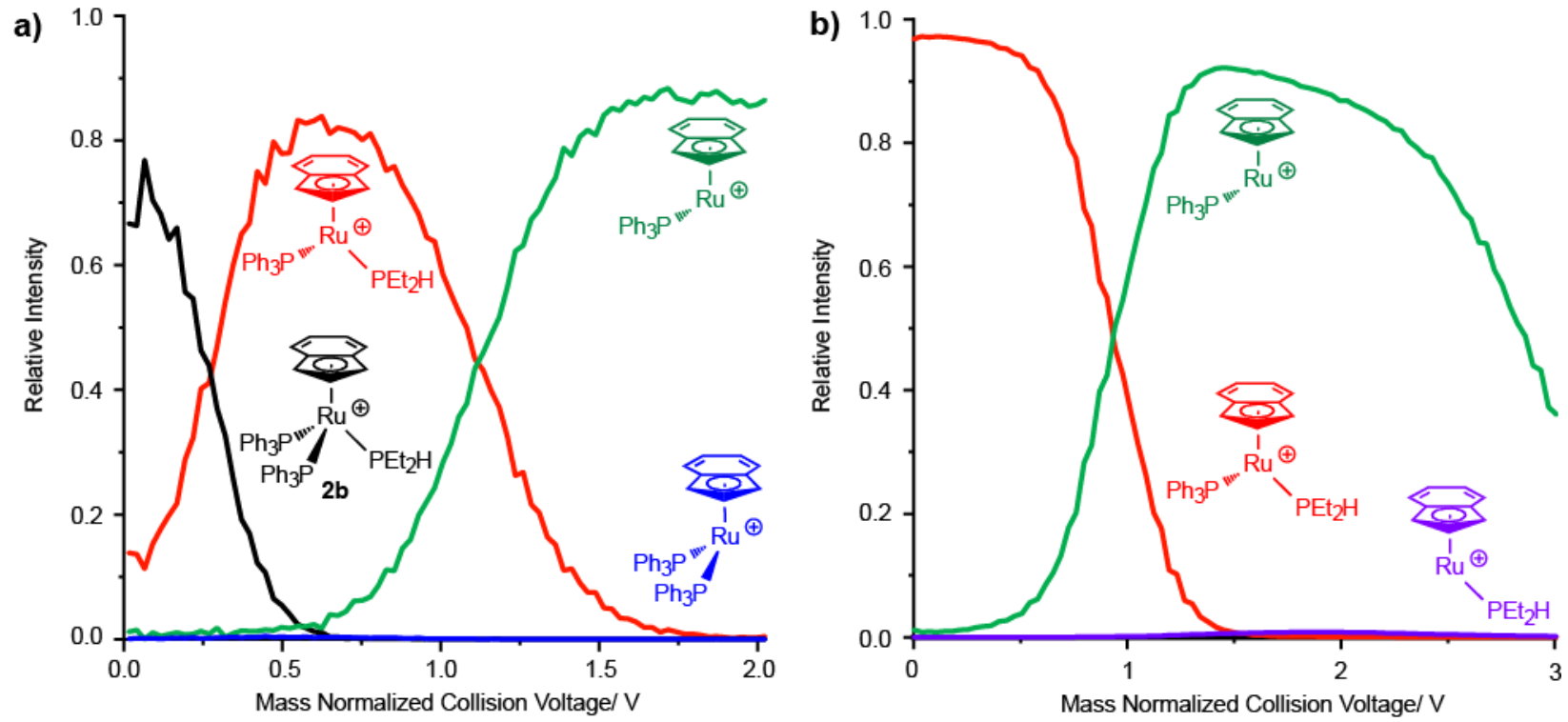

Figure 5. Breakdown curves observed in MS/MS experiments for (a) $\left[\mathrm{Ru}\left(\eta^{5} \text {-indenyl }\right)\left(\mathrm{PPh}_{3}\right)_{2}\left(\mathrm{PEt}_{2} \mathrm{H}\right)\right]^{+}(\mathbf{2 b})$ and $(\mathrm{b})$ the in-source generated ion $\left[\mathrm{Ru}\left(\eta^{5} \text {-indenyl }\right)\left(\mathrm{PPh}_{3}\right)\left(\mathrm{PEt}_{2} \mathrm{H}\right)\right]^{+}$. In both experiments, $\left[\mathrm{Ru}\left(\eta^{5} \text {-indenyl }\right)\left(\mathrm{PPh}_{3}\right)\left(\mathrm{PEt}_{2} \mathrm{H}\right)\right]^{+}$converts cleanly into $\left[\mathrm{Ru}\left(\eta^{5}\right.\right.$ indenyl $\left.)\left(\mathrm{PPh}_{3}\right)\right]^{+}$without appreciable formation of $\left[\mathrm{Ru}\left(\eta^{5} \text {-indenyl }\right)\left(\mathrm{PEt}_{2} \mathrm{H}\right)\right]^{+}$.

\section{MS/MS experiments: unexpected evidence for gas-phase} orthometallation

We also used CID experiments to examine the gas phase, competitive dissociation chemistry of $\left[\mathrm{Ru}\left(\eta^{5}\right.\right.$ indenyl $\left.)\left(\mathrm{PPh}_{3}\right)_{2}\left(\mathrm{PR}_{2} \mathrm{H}\right)\right]^{+}$for $\mathrm{R}=\mathrm{Ph}(\mathbf{2 a})$ and Et (2b), since the reliably facile loss of $\mathrm{PPh}_{3}$ from these complexes to generate coordinatively unsaturated fragments $\left[\mathrm{Ru}\left(\eta^{5}\right.\right.$ indenyl $\left.)\left(\mathrm{PPh}_{3}\right)\left(\mathrm{PR}_{2} \mathrm{H}\right)\right]^{+}$should allow a simpler, two-way comparison of the binding energies of the remaining phosphines. We were surprised by the results of this experiment for the $\mathrm{PEt}_{2} \mathrm{H}$ complex $\mathbf{2 b}$ (Figure 5a); although we did observe almost exclusive initial loss of $\mathrm{PPh}_{3}$ to form $\left[\mathrm{Ru}\left(\eta^{5}\right.\right.$ indenyl $\left.)\left(\mathrm{PPh}_{3}\right)\left(\mathrm{PEt}_{2} \mathrm{H}\right)\right]^{+}{ }^{26}$ continued ramping of the collision voltage showed subsequent, exclusive loss of $\mathrm{PEt}_{2} \mathrm{H}$ to give $\left[\mathrm{Ru}\left(\eta^{5} \text {-indenyl }\right)\left(\mathrm{PPh}_{3}\right)\right]^{+}$, instead of the loss of a second equivalent of $\mathrm{PPh}_{3}$ that we expected based on the stronger donor ability of $\mathrm{PEt}_{2} \mathrm{H}$ (vide supra). This points to unusual stability of the gaseous $\left[\mathrm{Ru}\left(\eta^{5} \text {-indenyl }\right)\left(\mathrm{PPh}_{3}\right)\right]^{+}$fragment under the conditions of the CID experiment. We reproduced this result using an alternative experiment in which the ion $\left[\mathrm{Ru}\left(\eta^{5} \text {-indenyl }\right)\left(\mathrm{PPh}_{3}\right)\left(\mathrm{PEt}_{2} \mathrm{H}\right)\right]^{+}$was generated "in-source", by increasing the cone voltage such that the initial CID occurs during the desolvation process (Figure 5b). This allowed examination of the unsaturated precursor ion by MS/MS independently of the presence of potentially complicating fragments.

One possible explanation for the surprisingly facile loss of $\mathrm{PEt}_{2} \mathrm{H}$ and apparent stability of the $\left[\mathrm{Ru}\left(\eta^{5} \text {-indenyl }\right)\left(\mathrm{PPh}_{3}\right)\right]^{+}$ fragment $(\mathrm{m} / \mathrm{z}, 479)$ in these experiments involves gas-phase reactivity of the coordinatively unsaturated intermediate $\left[\mathrm{Ru}\left(\eta^{5} \text {-indenyl }\right)\left(\mathrm{PPh}_{3}\right)\left(\mathrm{PEt}_{2} \mathrm{H}\right)\right]^{+}$, which is "hot" (vibrationally excited) from collisions (Scheme 5). Although the pressure in the collision cell is too low to allow intermolecular ion-molecule reactivity, intramolecular reactions could occur. In particular, we propose that this 16-electron species undergoes orthometallation of the coordinated $\mathrm{PPh}_{3}$, a wellknown intramolecular $\mathrm{C}-\mathrm{H}$ activation reaction that occurs readily for $\mathrm{Ru}(\mathrm{II})$ complexes. $^{27}$ This would generate a
$\mathrm{Ru}(\mathrm{IV})$ species (complex A, Scheme 5), from which dissociation of the neutral secondary phosphine ligand $\mathrm{PEt}_{2} \mathrm{H}$ would now be favoured, relative to loss of the new hydride and $\kappa^{2}$ $\left(o-\mathrm{C}_{6} \mathrm{H}_{4} \mathrm{PPh}_{2}\right)$ ligands (fragment also $\mathrm{m} / \mathrm{z} 479$ ).

Scheme 5. Proposed gas-phase orthometallation chemistry resulting in preferential loss of $\mathrm{PEt}_{2} \mathrm{H}$ over $\mathrm{PPh}_{3}$ from $\left[\mathbf{R u}\left(\eta^{5} \text {-indenyl }\right)\left(\mathbf{P P h}_{3}\right)\left(\mathbf{P E t}_{2} \mathbf{H}\right)\right]^{+}$

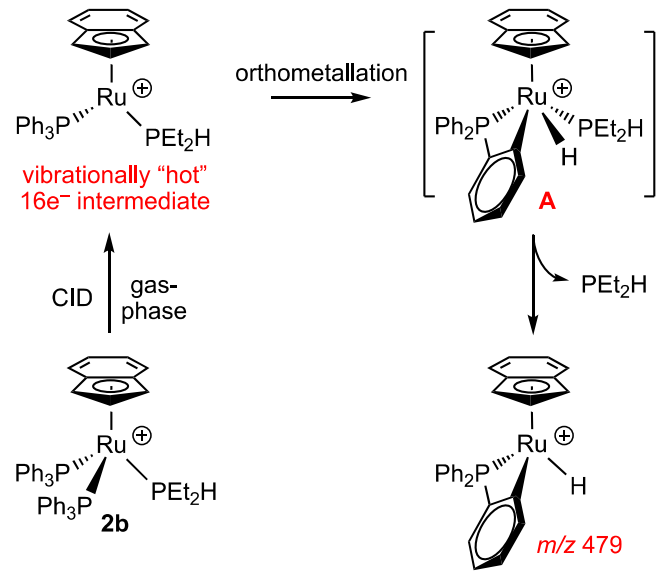

Similar results were obtained for CID experiments involving the $\mathrm{PPh}_{2} \mathrm{H}$ complex 2a (Figure S17), although in this case $\mathrm{PPh}_{2} \mathrm{H}$ was more competitive with $\mathrm{PPh}_{3}$, both for initial loss (about 2\% $\quad \mathrm{PPh}_{2} \mathrm{H}$ is lost from $\mathbf{2 a}$ to give the bis(triphenylphosphine) cation, compared to $0.1 \% \mathrm{PEt}_{2} \mathrm{H}$ dissociation from $\mathbf{2 b}$ ) and for the second ligand dissociation (about $5 \%$ of the $\mathrm{PPh}_{2} \mathrm{H}$ remains bound to $\mathrm{Ru}$, compared to $0 \%$ for $\mathrm{PEt}_{2} \mathrm{H}$ ). These observations are reasonable: $\mathrm{PPh}_{3}$ is lost more easily than $\mathrm{PPh}_{2} \mathrm{H}$ from $2 \mathbf{a}$ because it is significantly larger than $\mathrm{PPh}_{2} \mathrm{H}$ and there are two $\mathrm{PPh}_{3}$ ligands; also, as shown above, the $\mathrm{PPh}_{2} \mathrm{H}$ is a slightly stronger donor. In addition, $\mathrm{PPh}_{2} \mathrm{H}$ is able to participate in orthometallation, unlike $\mathrm{PEt}_{2} \mathrm{H}$ but like $\mathrm{PPh}_{3}$. However, its propensity to do so in this context is less for two reasons: $\mathrm{PPh}_{2} \mathrm{H}$ has just four 
ortho protons while $\mathrm{PPh}_{3}$ has six available to participate in the $\mathrm{C}-\mathrm{H}$ activation at $\mathrm{Ru}$, and significantly, the $\mathrm{PPh}_{3}$ ortho hydrogens are closer to the metal due to the larger $\mathrm{PPh}_{3}$ cone angle, relative to that for $\mathrm{PPh}_{2} \mathrm{H}$. Figure $\mathrm{S} 17$ shows that at very high collision energies, $\left[\mathrm{Ru}\left(\eta^{5} \text {-indenyl }\right)\left(\mathrm{PPh}_{2} \mathrm{H}\right)\right]^{+}$begins to form as a product of decomposition of $\left[\mathrm{Ru}\left(\eta^{5}-\right.\right.$ indenyl $\left.)\left(\mathrm{PPh}_{3}\right)\right]^{+}$, which corresponds to a loss of benzyne that can be attributed to a second orthometallation event.

\section{CONCLUSIONS}

We have demonstrated the facile evaluation of ligand substitution chemistry and relative binding strengths at cationic metal complexes, through straightforward solution and gasphase experiments involving PSI-ESI-MS. The kinetics of competitive ligand substitution reactions at a ruthenium indenyl cation as monitored by PSI-ESI-MS are reproduced comprehensively by those obtained for analogous experiments monitored by ${ }^{31} \mathrm{P}\left\{{ }^{1} \mathrm{H}\right\}$ NMR, despite a difference in solution concentrations of more than six orders of magnitude. These solution experiments examining mixtures of secondary and tertiary phosphines highlight especially the impact of steric crowding at the ruthenium indenyl fragment, which has implications for its activity in catalytic hydrophosphination chemistry; substrate secondary phosphines should compete well for binding in the presence of (at least) equimolar amounts of product tertiary phosphine. The ease of isolating gaseous cations containing two or three distinct phosphine ligands in the mass spectrometer allowed us to further parse relative Ru-P binding strengths in this system via competitive CID experiments. These gas-phase studies reinforce some of our conclusions from the solution studies concerning the balance of electronic and steric influences of secondary and tertiary phosphines in ruthenium coordination chemistry. However rigorous one-on-one comparison of phosphine binding energies is precluded for this halfsandwich system by apparent competing $\mathrm{C}-\mathrm{H}$ activation chemistry in the collision cell. Although such phosphine orthometallation is routinely observed in solution chemistry, its importance in gas-phase organometallic chemistry was not previously established.

\section{EXPERIMENTAL SECTION}

\section{General details and instrumentation}

Chemicals and reaction mixtures were all handled under inert gas atmosphere using standard glovebox and Schlenk techniques. Dichloromethane was freshly distilled from $\mathrm{CaH}$ or $\mathrm{P}_{2} \mathrm{O}_{5}$ and fluorobenzene was freshly distilled from $\mathrm{P}_{2} \mathrm{O}_{5}$ before use. Deuterated benzene $\left(\mathrm{C}_{6} \mathrm{D}_{6}\right)$ was stored over sodium/benzophenone and was degassed by three freeze-pump-thaw cycles and vacuumtransferred before use. All phosphines were purchased from Strem Chemicals Inc. and used without further purification. The ruthenium complex $\left[\mathrm{Ru}\left(\eta^{5} \text {-indenyl }\right)(\mathrm{NCPh})\left(\mathrm{PPh}_{3}\right)_{2}\right]^{+}\left[\mathrm{B}\left(\mathrm{C}_{6} \mathrm{~F}_{5}\right)_{4}\right]^{-}, \mathbf{1}\left[\mathrm{B}\left(\mathrm{C}_{6} \mathrm{~F}_{5}\right)_{4}\right]$, was synthesized by a literature method. ${ }^{1}$

Mass spectra were collected with a Micromass Q-Tof Micro mass spectrometer in positive ion mode. Key parameters: capillary voltage, $2800 \mathrm{~V}$; sample cone voltage, $10.0 \mathrm{~V}$; extraction cone voltage, $1.0 \mathrm{~V}$; desolvation temperature, $160{ }^{\circ} \mathrm{C}$; source temperature, 60 ${ }^{\circ} \mathrm{C}$; cone gas flow, $0 \mathrm{~L} / \mathrm{h}$; desolvation gas flow, $40 \mathrm{~L} / \mathrm{h}$; MCP voltage, $2700 \mathrm{~V}$; collision voltage (MS study), $2 \mathrm{~V}$; collision voltage (MS/MS study), programmed by Autohotkey (MassLynx) to increase the voltage by $1 \mathrm{~V}$ every 10.12 seconds from 0 to $100 \mathrm{~V}$. Mass spectrometric data was normalized to total ion current before conducting kinetic analysis (this normalization step accounts for differences in spray conditions from one spectrum to the next).
NMR spectra were recorded at ambient temperature (294K) on a Bruker AMX 360 spectrometer operating at $145.85 \mathrm{MHz}$ for ${ }^{31} \mathrm{P}$. Chemical shifts are reported in ppm. ${ }^{31} \mathrm{P}\left\{{ }^{1} \mathrm{H}\right\}$ chemical shifts are reported relative to $85 \% \mathrm{H}_{3} \mathrm{PO}_{4}(\mathrm{aq})$.

Ligand substitution reactions monitored using pressurized sample infusion (PSI)

An argon-pressurized (3 psi) Schlenk flask containing a solution of $\mathbf{1}\left[\mathrm{B}\left(\mathrm{C}_{6} \mathrm{~F}_{5}\right)_{4}\right](0.2 \mathrm{mg}, 0.1 \mu \mathrm{mol})$ in fluorobenzene $(10.5 \mathrm{ml})$ heated to $45{ }^{\circ} \mathrm{C}$ (or $60{ }^{\circ} \mathrm{C}$ for experiments with $\mathrm{Ph}_{2} \mathrm{PCH}_{2} \mathrm{CH}_{2} \mathrm{CO}_{2} \mathrm{Bu}^{t}$ ) was connected to the mass spectrometer via PEEK tubing, and a stable signal established for the cation $\mathbf{1}$. The reaction was initiated by the injection of a fluorobenzene solution $(0.5 \mathrm{ml})$ of 10,50 or 100 equiv of phosphine ligand(s). Amounts used: $\mathrm{PPh}_{2} \mathrm{H}(100$ equiv, $13 \mu \mathrm{mol}, 36 \mu \mathrm{L} ; 10$ equiv, $1.3 \mu \mathrm{mol}, 3.6 \mu \mathrm{L}) ; \mathrm{PEt}_{2} \mathrm{H}(100$ equiv, $13 \mu \mathrm{mol}, 18 \mu \mathrm{L}$; 10 equiv, $1.3 \mu \mathrm{mol}, 1.8 \mu \mathrm{L}) ; \mathrm{PCy} 2 \mathrm{H}(100$ equiv, $13 \mu \mathrm{mol}, 39 \mu \mathrm{L}$; 10 equiv, $1.3 \mu \mathrm{mol}, 3.9 \mu \mathrm{L}) ; \mathrm{PBu}^{n}{ }_{3}(100$ equiv, $13 \mu \mathrm{mol}, 3.3 \mu \mathrm{L}$; 50 equiv, $6.5 \mu \mathrm{mol}, 1.6 \mu \mathrm{L} ; 10$ equiv, 1.3 $\mu \mathrm{mol}, 0.33 \mu \mathrm{L}$ ); $\mathrm{Ph}_{2} \mathrm{PCH}_{2} \mathrm{CH}_{2} \mathrm{CO}_{2} \mathrm{Bu}^{t}$ (10 equiv, $1.3 \mu \mathrm{mol}, 7 \mathrm{mg}$ ).

Ligand substitution reactions monitored using ${ }^{31} \mathrm{P}\left\{{ }^{1} \mathrm{H}\right\} N M R$

Complex $\mathbf{1}\left[\mathrm{B}\left(\mathrm{C}_{6} \mathrm{~F}_{5}\right)_{4}\right](30 \mathrm{mg}, 20 \mu \mathrm{mol})$ was dissolved in a mixture of dichloromethane $(0.4 \mathrm{~mL})$ and $\mathrm{C}_{6} \mathrm{D}_{6}(0.2 \mathrm{~mL})$ and 1,10 , or 20 equiv of various phosphine ligands were added. Amounts used: $\mathrm{PPh}_{2} \mathrm{H}$ (10 equiv, $0.20 \mathrm{mmol}, 35 \mu \mathrm{L}$; 1 equiv, $20 \mu \mathrm{mol}, 3.5 \mu \mathrm{L}$ ), $\mathrm{PEt}_{2} \mathrm{H}$ (10 equiv, $0.20 \mathrm{mmol}, 23 \mu \mathrm{L}$ ), $\mathrm{PCy} 2 \mathrm{H}$ (10 equiv, $0.20 \mathrm{mmol}$, $44 \mu \mathrm{L}$ ), $\mathrm{PBu}_{3}{ }_{3}$ (10 equiv, $0.20 \mathrm{mmol}, 50 \mu \mathrm{L}$ ), $\mathrm{Ph}_{2} \mathrm{PCH}_{2} \mathrm{CH}_{2} \mathrm{CO}_{2} \mathrm{Bu}^{i}$ (10 equiv, $0.20 \mathrm{mmol}, 62 \mathrm{mg}$ ). The progress of the reactions was monitored by ${ }^{31} \mathrm{P}\left\{{ }^{1} \mathrm{H}\right\}$ NMR using a relaxation delay (D1) of $10 \mathrm{~s}$.

$M S / M S$ studies examining competitive ligand dissociation from $\left[R u\left(\eta^{5} \text {-indenyl }\right) P P^{\prime} P^{\prime \prime}\right]^{+}$and $\left[R u\left(\eta^{5} \text {-indenyl }\right) P P^{\prime}\right]^{+}$

The $\left[\mathrm{Ru}\left(\eta^{5}\right.\right.$-indenyl)PP'P"'] ${ }^{+}$complexes $\mathbf{5}$ and $\mathbf{6}$ were prepared in situ by adding 10 equiv each of two secondary phosphine ligands to a solution of $1\left[\mathrm{~B}\left(\mathrm{C}_{6} \mathrm{~F}_{5}\right)_{4}\right](2 \mathrm{mg}, 1 \mu \mathrm{mol})$ in dichloromethane (5 $\mathrm{mL})$. The $\left[\mathrm{Ru}\left(\eta^{5} \text {-indenyl }\right) \mathrm{PP}^{\prime}\right]^{+}$complexes were generated during the MS/MS experiment from precursor complexes $\left[\mathrm{Ru}\left(\eta^{5}\right.\right.$ indenyl) $\left.\left(\mathrm{PPh}_{3}\right)_{2}\left(\mathrm{PR}_{2} \mathrm{H}\right)\right]^{+}(\mathrm{R}=\mathrm{Ph}(\mathbf{2 a})$, Et (2b)), which were prepared in situ by the addition of 10 equiv of one secondary phosphine ligand to a solution of $1\left[\mathrm{~B}\left(\mathrm{C}_{6} \mathrm{~F}_{5}\right)_{4}\right](2 \mathrm{mg}, 1 \mu \mathrm{mol})$ in dichloromethane $(5 \mathrm{~mL})$. Amounts used: diphenylphosphine $(36 \mu \mathrm{L}, 13$ $\mu \mathrm{mol})$; diethylphosphine $(18 \mu \mathrm{L}, 13 \mu \mathrm{mol})$; dicyclohexylphosphine (39 $\mu \mathrm{L}, 13 \mu \mathrm{mol})$.

MS/MS data for these tris(phosphine) complexes were collected by isolating in the collision cell the appropriate $\mathrm{m} / \mathrm{z}$, value for the precursor ion of interest, and increasing the collision voltage $1 \mathrm{~V}$ every 10 seconds while observing the resulting product ions.

Additional, analogous MS/MS experiments were performed on coordinatively unsaturated $\left[\mathrm{Ru}\left(\eta^{5} \text {-indenyl }\right) \mathrm{PP}^{\prime}\right]^{+}$complexes that were generated from the solutions containing $\mathbf{2 a - b}$ by increasing the sample cone voltage to $30 \mathrm{~V}$, to dissociate the most weakly bound phosphine ligand during the in-source desolvation process.

\section{ASSOCIATED CONTENT}

\section{Supporting Information}

Additional reaction monitoring data acquired using ESI-MS and ${ }^{31} \mathrm{P}\left\{{ }^{1} \mathrm{H}\right\}$ NMR, and additional MS-MS data (pdf).

The Supporting Information is available free of charge on the ACS Publications website.

\section{AUTHOR INFORMATION}

\section{Corresponding Authors}

*Email: lisarose@uvic.ca, mcindoe@uvic.ca Notes

The authors declare no competing financial interests.

\section{ACKNOWLEDGMENT}

JSM thanks NSERC (Discovery and Discovery Accelerator Supplements) for operational funding and CFI, BCKDF and the 
University of Victoria for infrastructural support. LR thanks NSERC (Discovery) for funding. RGB thanks University of Victoria (graduate fellowship) and NSERC (CGS-M and PGSD) for funding.

\section{REFERENCES}

(1) Belli, R. G.; Burton, K. M. E.; Rufh, S. A.; McDonald, R.; Rosenberg, L. Inner- and outer-sphere roles of ruthenium phosphido complexes in the hydrophosphination of alkenes. Organometallics 2015, 34, 5637-5646.

(2) Leading references for the use of the $\mathrm{Ru}\left(\eta^{5}\right.$-indenyl) fragment in catalysis: (a) Trost, B. M.; Ryan, M. C.; Maurer, D. Development of a coordinatively unsaturated chiral indenylruthenium catalyst. Org. Lett. 2016, 18, 3166-3169; (b) Trost, B. M.; Ryan, M. C. Indenylmetal catalysis in organic synthesis. Angew. Chem. Int. Ed. 2016, 56, 2862-2879; (c) Manzini, S.; Fernández-Salas, J. A.; Nolan, S. P. From a decomposition product to an efficient and versatile catalyst: the $\left[\mathrm{Ru}\left(\eta^{5}\right.\right.$-indenyl $\left.)\left(\mathrm{PPh}_{3}\right)_{2} \mathrm{Cl}\right]$ story. Acc. Chem. Res. 2014, 47, 3089-3101; (d) Thamapipol, S.; Kündig, E. P. Intramolecular Diels-Alder reactions using chiral ruthenium Lewis acids and application in the total synthesis of ent-ledol. Org. Biomol. Chem. 2011, 9, 7564-7570; (e) Fung, W. K.; Huang, X.; Man; ManNg, S. M.; Hung, M. Y.; Lin, Z.; Lau, C. P. Dihydrogenbond-promoted catalysis: catalytic hydration of nitriles with the indenylruthenium hydride complex $\left(\eta^{5}-\mathrm{C}_{9} \mathrm{H}_{7}\right) \mathrm{Ru}(\mathrm{dppm}) \mathrm{H}(\mathrm{dppm}=$ bis(diphenylphosphino)methane). J. Am. Chem. Soc. 2003, 125, 11539-11544; (f) Alvarez, P.; Gimeno, J.; Lastra, E.; GarcíaGranda, S.; Van der Maelen, J. F.; Bassetti, M. Synthesis and reactivity of indenyl ruthenium(II) complexes containing the labile ligand 1,5-cyclooctadiene (COD): catalytic activity of $\left[\mathrm{Ru}\left(\eta^{5}\right.\right.$ $\left.\left.\mathrm{C}_{9} \mathrm{H}_{7}\right) \mathrm{Cl}(\mathrm{COD})\right]$. Organometallics 2001, 20, 3762-3771; (g) Koh, J. H.; Jung, H. M.; Kim, M.-J.; Park, J. Enzymatic resolution of secondary alcohols coupled with ruthenium-catalyzed racemization without hydrogen mediator. Tetrahedron Lett. 1999, 40, 6281-6284; (h) Yamamoto, Y.; Kitahara, H.; Hattori, R.; Itoh, K. Rutheniumcatalyzed tandem $[2+2+2] /[4+2]$ cycloaddition of $1,6-$ heptadiyne with norbornene. Organometallics 1998, 17, 1910-1912.

(3) The activity of a RuCp* complex in similar hydrophosphination chemistry has been reported. Sues, P. E.; Lough, A. J.; Morris, R. H. Reactivity of ruthenium phosphido species generated through the deprotonation of a tripodal phosphine ligand and implications for hydrophosphination. J. Am. Chem. Soc. 2014, 136, 4746-4760.

(4) (a) Santiago, C. B.; Guo, J.-Y.; Sigman, M. S. Predictive and mechanistic multivariate linear regression models for reaction development. Chem. Sci. 2018, 9, 2398-2412; (b) Fey, N.; Orpen, A. G.; Harvey, J. N. Building ligand knowledge bases for organometallic chemistry: Computational description of phosphorus(III)-donor ligands and the metal-phosphorus bond. Coord. Chem. Rev. 2009, 253, 704-722; (c) Leyssens, T.; Peeters, D.; Orpen, A. G.; Harvey, J. N. How important is metal-ligand back-bonding toward $\mathrm{YX}_{3}$ ligands $(\mathrm{Y}=\mathrm{N}, \mathrm{P}, \mathrm{C}, \mathrm{Si})$ ? An NBO analysis. Organometallics 2007, 26, 2637-2645; (d) Tolman, C. A. Steric effects of phosphorus ligands in organometallic chemistry and homogeneous catalysis. Chem. Rev. 1977, 77, 313-348.

(5) See reference 4d. These calculations may not accurately reflect the much tighter C-P-H angles $\left(95-97^{\circ}\right)$ in secondary phosphines relative to the C-P-C angles in tertiary phosphines (99 $110^{\circ}$ ). Quin, L. D., A Guide to Organophosphorus Chemistry. Wiley:Hoboken: NJ, 2000.

(6) Percent buried volume $\left(\% \mathrm{~V}_{\text {bur }}\right)$ is an important ligand steric parameter that can complement the Tolman cone angle in describing the steric influence of phosphines on catalytic reactions. Wu, K.; Doyle, A. G. Parameterization of phosphine ligands demonstrates enhancement of nickel catalysis via remote steric effects. Nature Chem. 2017, 9, 779; and references therein.

(7) For recent review of the coordination chemistry of secondary phosphines see: Nell, B. P.; Tyler, D. R. Synthesis, reactivity, and coordination chemistry of secondary phosphines. Coord. Chem. Rev. 2014, 279, 23-42.
(8) Chisholm, D. M.; Scott McIndoe, J. Charged ligands for catalyst immobilisation and analysis. Dalton Trans. 2008, 39333945.

(9) In ESI-MS, neutral molecules often appear as $[\mathrm{M}+\mathrm{H}]+$ ions, for example, and their intensity in spectra is thus strongly dependent on a combination of basicity and surface activity.

(10) Westmore, J. B.; Rosenberg, L.; Hooper, T. S.; Willett, G. D.; Fisher, K. J. Determination of ruthenium-phosphorus bond dissociation energies by ES-FTICR mass spectrometry. Organometallics 2002, 21, 5688-5691.

(11) Luo, L.; Nolan, S. P. Relative binding energies of sterically demanding tertiary phosphine ligands to the $\mathrm{Cp} * \mathrm{RuCl}\left(\mathrm{Cp}^{*}=\eta^{5}\right.$ $\left.\mathrm{C}_{5} \mathrm{Me}_{5}\right)$ moiety. Thermochemical investigation of coordinatively unsaturated organoruthenium complexes. Organometallics 1994, $13,4781-4786$

(12) (a) Vikse, K. L.; Ahmadi, Z.; Luo, J.; van der Wal, N.; Daze, K.; Taylor, N.; McIndoe, J. S. Pressurized sample infusion: An easily calibrated, low volume pumping system for ESI-MS analysis of reactions. Int. J. Mass Spectrom. 2012, 323-324, 8-13; (b) Vikse, K. L.; Woods, M. P.; McIndoe, J. S. Pressurized sample infusion for the continuous analysis of air- and moisture-sensitive reactions using electrospray ionization mass spectrometry. Organometallics 2010, 29, 6615-6618.

(13) Chisholm, D. M.; Oliver, A. G.; McIndoe, J. S. Monoalkylated bisphosphines as dopants for ESI-MS analysis of catalytic reactions. Dalton Trans. 2010, 39, 364-373.

(14) (a) Hartwig, J. F., Organotransition Metal Chemistry: From Bonding to Catalysis. University Science Books: 2010, p.250; (b) Crabtree, R. H., The Organometallic Chemistry of the Transition Metals. 5th ed.; Wiley:Hoboken: NJ, 2009, p.110.

(15) The seminal examples of $\eta^{5}$ - to $\eta^{3}$-hapticity changes include complexes from group 9 and group 6 . See reference $14 \mathrm{a}$ and references therein.

(16) (a) Bassetti, M.; Casellato, P.; Gamasa, M. P.; Gimeno, J.; González-Bernardo, C.; Martín-Vaca, B. Insertion reactions of alkynes into the $\mathrm{Ru}-\mathrm{H}$ bond of indenylruthenium(II) hydride complexes. Mechanism of the reaction of phenylacetylene with $\left[\mathrm{RuH}\left(\eta^{5}-\mathrm{C}_{9} \mathrm{H}_{7}\right)(\mathrm{dppm})\right](\mathrm{dppm}=$ bis $($ diphenylphosphino)methane $)$. Organometallics 1997, 16, 5470-5477; (b) Gamasa, M. P.; Gimeno, J.; Gonzalez-Bernardo, C.; Martín-Vaca, B. M.; Monti, D.; Bassetti, M. Phosphine substitution in indenyl- and cyclopentadienylruthenium complexes. Effect of the $\eta^{5}$ ligand in a dissociative pathway. Organometallics 1996, 15, 302-308.

(17) For discussion of ground state contributions to the indenyl effect, arising from weaker binding of the $\eta^{5}$-indenyl ligand relative to $\eta^{5}$-Cp at coordinatively saturated metals, see: (a) Calhorda, M. J.; Romão, C. C.; Veiros, L. F. The nature of the indenyl effect. Chem. Eur. J. 2002, 8, 868-875; (b) Kubas, G. J.; Kiss, G.; Hoff, C. D. Solution calorimetric, equilibrium, and synthetic studies of oxidative addition/reductive elimination of cyclopentadiene derivatives, $\mathrm{C}_{5} \mathrm{R}_{5} \mathrm{H}(\mathrm{R}=\mathrm{H}, \mathrm{Me}$, indenyl $)$, to/from the metal complexes $\mathrm{M}(\mathrm{CO})_{3}(\mathrm{RCN})_{3} /\left(\eta^{5}-\mathrm{C}_{5} \mathrm{R}_{5}\right) \mathrm{M}(\mathrm{CO})_{3} \mathrm{H} \quad(\mathrm{M}=$ chromium, molybdenum, tungsten). Organometallics 1991, 10, 2870-2876.

(18) Pauling, L., College Chemistry. 2nd ed.; WH. Freeman and Company: San Francisco, CA, 1957, p.406.

(19) Foley, D. A.; Dunn, A. L.; Zell, M. T. Reaction monitoring using online vs tube NMR spectroscopy: seriously different results. Magn. Reson. Chem. 2015, 54, 451-456.

(20) Hoops, S.; Sahle, S.; Gauges, R.; Lee, C.; Pahle, J.; Simus, N.; Singhal, M.; Xu, L.; Mendes, P.; Kummer, U. COPASI-a COmplex PAthway SImulator. Bioinformatics 2006, 22, 3067-3074.

(21) For a previous example of the use of COPASI in conjunction with reaction monitoring data obtained from ESI-MS, see: Luo, J.; Theron, R.; Sewell, L. J.; Hooper, T. N.; Weller, A. S.; Oliver, A. G.; McIndoe, J. S. Rhodium-catalyzed selective partial hydrogenation of alkynes. Organometallics 2015, 34, 3021-3028.

(22) See for examples: (a) Bamford, K. L.; Chitnis, S. S.; Stoddard, R. L.; McIndoe, J. S.; Burford, N. Bond fission in monocationic frameworks: diverse fragmentation pathways for phosphinophosphonium cations. Chem. Sci. 2016, 7, 2544-2552; (b) 
Pike, S. D.; Pernik, I.; Theron, R.; McIndoe, J. S.; Weller, A. S. Relative binding affinities of fluorobenzene ligands in cationic rhodium bisphosphine $\eta^{6}$-fluorobenzene complexes probed using collision-induced dissociation. J. Organomet. Chem. 2015, 784, 7583.

(23) See for examples reference10 and (a) Couzijn, E. P. A.; Zocher, E.; Bach, A.; Chen, P. Gas-phase energetics of reductive elimination from a palladium(II) $\mathrm{N}$-heterocyclic carbene complex. Chem. Eur. J. 2010, 16, 5408-5415; (b) Torker, S.; Merki, D.; Chen, P. Gas-phase thermochemistry of ruthenium carbene metathesis catalysts. J. Am. Chem. Soc. 2008, 130, 4808-4814.

(24) Kobylianskii, I. J.; Widner, F. J.; Kräutler, B.; Chen, P. Co$\mathrm{C}$ bond energies in adenosylcobinamide and methylcobinamide in the gas phase and in silico. J. Am. Chem. Soc. 2013, 135, 1364813651.

(25) (a) Butcher, C. P. G.; Dyson, P. J.; Johnson, B. F. G.; Langridge-Smith, P. R. R.; McIndoe, J. S.; Whyte, C. On the use of breakdown graphs combined with energy-dependent mass spectrometry to provide a complete picture of fragmentation processes. Rapid Commun. Mass Spectrom. 2002, 16, 1595-1598; (b) Weinmann, W.; Stoertzel, M.; Vogt, S.; Wendt, J. Tune compounds for electrospray ionisation/in-source collision-induced dissociation with mass spectral library searching. J. Chromatogr. A 2001, 926, 199-209; (c) Weinmann, W.; Stoertzel, M.; Vogt, S.; Svoboda, M.; Schreiber, A. Tuning compounds for electrospray ionization/in-source collision-induced dissociation and mass spectra library searching. J. Mass Spectrom. 2001, 36, 1013-1023; (d) Begala, M.; Delogu, G.; Maccioni, E.; Podda, G.; Tocco, G.; Quezada, E.; Uriarte, E.; Fedrigo, M. A.; Favretto, D.; Traldi, P. Electrospray ionisation tandem mass spectrometry in the characterisation of isomeric benzofurocoumarins. Rapid Commun.
Mass Spectrom. 2001, 15, 1000-1010; (e) Harrison, A. G. Energyresolved mass spectrometry: a comparison of quadrupole cell and cone-voltage collision-induced dissociation. Rapid Commun. Mass Spectrom. 1999, 13, 1663-1670; (f) Dookeran, N. N.; Yalcin, T.; Harrison, A. G. Fragmentation reactions of protonated $\alpha$-amino acids. J. Mass Spectrom. 1996, 31, 500-508.

(26) We did see trace quantities of $\left[\mathrm{Ru}\left(\eta^{5} \text {-indenyl }\right)\left(\mathrm{PPh}_{3}\right)_{2}\right]^{+}$in this MS/MS experiment, but at less than 1/1000th the (normalized) intensity of signal due to $\left[\mathrm{Ru}\left(\eta^{5} \text {-indenyl }\right)\left(\mathrm{PPh}_{3}\right)\left(\mathrm{PR}_{2} \mathrm{H}\right)\right]^{+}$(see Figure 5a).

(27) (a) Derrah, E. J.; Pantazis, D. A.; McDonald, R.; Rosenberg, $\mathrm{L}$. A highly reactive ruthenium phosphido complex exhibiting $\mathrm{Ru}-\mathrm{P}$

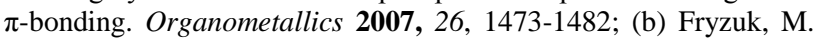
D.; Montgomery, C. D.; Rettig, S. J. Synthesis and reactivity of ruthenium amide-phosphine complexes. Facile conversion of a ruthenium amide to a ruthenium amine via dihydrogen activation and orthometalation. $\mathrm{X}$-ray structure of $\mathrm{RuCl}\left(\mathrm{C}_{6} \mathrm{H}_{4} \mathrm{PPh}_{2}\right)\left[\mathrm{NH}\left(\mathrm{SiMe}_{2} \mathrm{CH}_{2} \mathrm{PPh}_{2}\right)_{2}\right]$. Organometallics 1991, 10, 467-473; (c) Cole-Hamilton, D. J.; Wilkinson, G. The reactions of dihydridotetrakis(triphenylphosphine)ruthenium(II),

tetrakishydridotris(triphenylphosphine)ruthenium(II) and hydrido$\left(\eta^{3}-2-\right.$

diphenylphosphinophenyl)bis(triphenylphosphine)ruthenium(II) with alkenes, dienes, ketones, aldehydes and weak acids. Nouv. J. Chim. 1977, 1, 141-55; (d) James, B. R.; Markham, L. D.; Wang, D. K. W. Stoicheiometric hydrogenation of olefins using $\mathrm{HRuCl}\left(\mathrm{PPh}_{3}\right)_{3}$ and formation of an ortho-metallated ruthenium(II) complex. J. Chem. Soc., Chem. Commun. 1974, 439-440. 
For Table of Contents Only

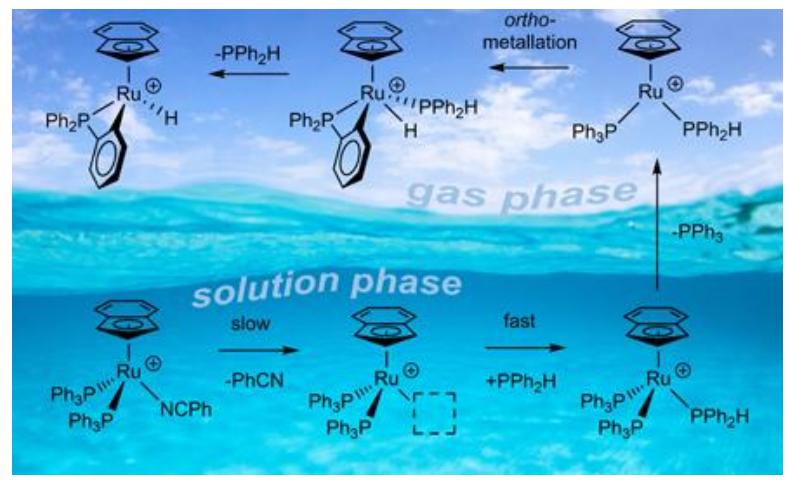

Competitive binding of secondary and tertiary phosphines at a ruthenium indenyl complex reveals a textbook dissociative substitution reaction whether studied at nanomolar concentrations by ESI-MS or at millimolar concentrations by NMR, and provides, along with gas phase dissociation experiments, an order of binding strengths for different phosphines. Fragmentation of unsaturated species show that these activated complexes undergo orthometallation reactions. 